\title{
How $\mathrm{NaCl}$ and water content determine water activity during ripening of Gouda cheese, and the predicted effect on inhibition of Listeria monocytogenes
}

\author{
E. Wemmenhove, ${ }^{\star} \dagger \ddagger$ M. H. J. Wells-Bennik, ${ }^{* 1}$ A. Stara, ${ }^{*}$ A. C. M. van Hooijdonk, $†$ and M. H. Zwietering \\ *NIZO Food Research, 6710 BA Ede, the Netherlands \\ †Food Quality and Design, and \\ łLaboratory of Food Microbiology, Wageningen University, 6700AA Wageningen, the Netherlands
}

\begin{abstract}
This study describes the diffusion of $\mathrm{NaCl}$ and water in Gouda cheese during brining and ripening. Furthermore, we established water activity as a function of the NaCl-in-moisture content in Gouda cheese during ripening. We determined $\mathrm{NaCl}$ content, water content, and water activity in block-type Gouda cheeses that were brined for $3.8 \mathrm{~d}$ and foil-ripened for a period of 26 wk, and in wheel-type Gouda cheeses that were brined for $0.33,2.1$, or $8.9 \mathrm{~d}$ and subsequently nature-ripened for a period of $26 \mathrm{wk}$. The calculated diffusion coefficients of $\mathrm{NaCl}$ during brining were $3.6 \cdot 10^{-10} \mathrm{~m}^{2} \mathrm{~s}^{-1}$ in the block-type Gouda cheeses and $3.5 \cdot 10^{-10} \mathrm{~m}^{2} \mathrm{~s}^{-1}$ in the wheel-type Gouda cheeses. Immediately after brining, gradients of $\mathrm{NaCl}$ and water were observed throughout both types of cheese. During ripening, these gradients disappeared, except for the water gradient in natureripened cheeses. An empirical model was derived for Gouda cheese, in which water activity is expressed as a function of the NaCl-in-moisture content, as established for different brining times, locations and ripening times. Moreover, the effect of reduced water activity on inhibition of growth of Listeria monocytogenes in Gouda cheese was calculated. In addition to the presence of lactate and a $\mathrm{pH}$ of 5.2 to 5.3 , the reduced water activity as seen in Gouda cheese can substantially contribute to inhibition of microbial growth and even to inactivation when cheeses are brined and ripened for extended times and subjected to nature-ripening.
\end{abstract}

Key words: Gouda, water activity, Listeria monocytogenes, salt content

\section{INTRODUCTION}

Gouda cheese is a ready-to-eat (RTE) product that is made from pasteurized cow milk. Many factors con-

Received October 14, 2015.

Accepted February 14, 2016.

${ }^{1}$ Corresponding author: marjon.wells-bennik@nizo.com tribute to the microbial safety and quality of Gouda cheese. This includes pasteurization of raw milk $\left(72^{\circ} \mathrm{C}\right.$ for $15 \mathrm{~s}$ ), hygienic processing, use of acidifying starter cultures during curd formation, and salting or brining after pressing of the curd. The intrinsic properties of cheese, such as the presence of organic acids and a low $\mathrm{pH}$, but also reduced water activity due to the presence of $\mathrm{NaCl}$, are important factors to control the outgrowth of undesirable microorganisms (Koutsoumanis and Sofos, 2005). Gouda cheese has a typical $\mathrm{pH}$ value of 5.2 to 5.3 , due to the activity of the starter lactic acid bacteria (including Lactococcus lactis and Leuconostoc mesenteroides) that convert lactose to lactic acid. Salt is introduced by immersing Gouda cheeses in brine (that typically has a $\mathrm{pH}$ of 4.4 and contains $18-19 \%$ wt/vol sodium chloride) for 2 to $4 \mathrm{~d}$ at 12 to $13^{\circ} \mathrm{C}$. The brining time is chosen based on the desired final sodium chloride $(\mathrm{NaCl})$ content and on the geometry and mass of the cheese. The average water activity of Gouda is 0.95 , but this value depends on the exact position within the cheese (e.g., closer to the rind or the core), and it changes during brining and ripening due to salt and water migration (Guinee and Fox, 2004). Ripening conditions of Gouda cheese can vary. Natureripened Gouda cheeses (usually wheel-type cheeses) are turned and coated regularly during ripening and are stored on wooden shelves at 12 to $13^{\circ} \mathrm{C}$ for a period of 4 wk up to more than 1 yr. Foil-ripened Gouda cheeses (block-type cheeses) are wrapped in plastic and ripened for 4 to 8 wk at $\sim 5^{\circ} \mathrm{C}$, and these cheeses are not coated and turned.

An important microbiological hazard for dairy foods such as cheese is the bacterium Listeria monocytogenes (Greig and Ravel, 2009), which is the causative agent of listeriosis (Vázquez-Boland et al., 2001), a disease that can have a case-fatality rate as high as 20 to $30 \%$ (Swaminathan and Gerner-Smidt, 2007). The organism can grow at low temperatures and is highly tolerant to salt and acid (Lou and Yousef, 2000). Microbiological criteria have been set in European Union regulation EC 2073/2005 (European Commission, 2005) for L. mono- 
cytogenes in RTE foods such as Gouda cheese. Based on these criteria, Gouda belongs to the category of RTE foods not intended for infants and medical purposes that can potentially support growth of $L$. monocytogenes, as the shelf life is $>5 \mathrm{~d}$, the average $\mathrm{pH}>5.0$, and the average water activity $>0.94$.

Since the recognition of $L$. monocytogenes as the causative agent in the 1980s (Schlech et al., 1983), listeriosis has mainly been associated with consumption of Mexican-style cheeses (Silk et al., 2012), with soft cheeses made from pasteurized milk (Koch et al., 2010; Gaulin et al., 2012; Gould et al., 2014) and Mimolette cheese (Yde et al., 2012), but not with consumption of Dutch-type cheeses such as Gouda and Maasdam or with Emmental. The latter cheeses do not support growth of L. monocytogenes in challenge studies with the pathogen (Northolt et al., 1988; Buazzi et al., 1992; Bachmann and Spahr, 1995; Wemmenhove et al., 2013, 2014). Undissociated lactic acid present in Gouda cheese plays an important role in inhibition of growth of this pathogen: we recently demonstrated that the highest concentration required to inhibit all growth of 6 different L. monocytogenes strains is 9.0 $\mathrm{m} M$, and that this is around the same level as the average concentration of undissociated lactic acid that is typically present in Gouda cheese; that is, $9.2 \mathrm{mM}$ at $\mathrm{pH} 5.3$ based on $13.9 \mathrm{~g}$ of lactic acid $\mathrm{kg}^{-1}$ cheese (Wemmenhove et al., 2016).

In addition to the effect of undissociated lactic acid, the major salt in Gouda cheese, $\mathrm{NaCl}$, may further contribute to inhibition of growth of $L$. monocytogenes due to its effect on water activity of the cheese. At low water activities, less water is freely available for bacteria, which can lead to inhibition of growth. Water activity $\left(\boldsymbol{a}_{\boldsymbol{w}}\right)$ is a physicochemical parameter equivalent to the vapor pressure of water in a system $(p)$ divided by the vapor pressure of pure water $\left(p_{0}\right)$ :

$$
a_{w}=\frac{p}{p_{0}}
$$

The effect of water activity on inhibition of growth of foodborne pathogens has been modeled together with other factors in secondary models based on the Gamma concept (Zwietering et al., 1993) that is widely used. According to this model, the inhibiting effect of water activity is expressed in the gamma factor for growth $\left(\gamma_{a_{w}}\right)$, which can be calculated as follows if $a_{w}>a_{w_{\min }}$ :

$$
\gamma_{a_{w}}=\frac{a_{w}-a_{w_{\min }}}{1-a_{w_{\min }}}
$$

in which $a_{w}$ is the water activity that is actually present in the cheese, and $a_{w_{\min }}$ is the minimal water activity at which growth of a bacterium can occur; $a_{w_{\min }}$ is 0.92 for L. monocytogenes according to ICMSF (1996). If the water activity is $>0.92$, it can still contribute to inhibition of growth of L. monocytogenes and growth can be fully inhibited when other factors are also present (e.g., $\mathrm{pH}$, organic acids), according to the Gamma concept (Zwietering et al., 1993).

As indicated above, $\mathrm{NaCl}$ is added to Gouda cheese during brining and is the major salt that affects the water activity of this product. It migrates into the cheese during brining and ripening, and water migrates from the cheese to the brine. Resnik and Chirife (1988) predicted the theoretical water activity based on measurements in saturated $\mathrm{NaCl}$ solutions at a temperature ranging from 15 to $50^{\circ} \mathrm{C}$ :

$$
a_{w}=e^{\left(\frac{\varphi \cdot v_{i} \cdot m_{i}}{-55.51}\right)}
$$

in which $\varphi$ is the ionic strength and $v_{i}$ is the number of particles into which each solute of molality $m_{i}$ dissociates.

Several empirical models are available for other types of cheese in which the water activity depends on the solutes (e.g., $\mathrm{NaCl}$ ) and water content of the cheese. In those models, the $\mathrm{NaCl}$ content is expressed as $\mathrm{NaCl}-$ in-moisture (\%,wt/wt). An empirical model has been established for fresh cheeses with a water-in-cheese content $\geq 40 \%$ by Marcos et al. $(1981,1983)$ :

$$
a_{w}=1.00-0.00565 \cdot[\mathrm{NaCl}]_{\mathrm{H}_{2} \mathrm{O}},
$$

in which $[\mathrm{NaCl}]_{\mathrm{H}_{2} \mathrm{O}}$ is $\mathrm{NaCl}$-in-moisture (\%, wt/wt).

In addition, Saurel et al. (2004) proposed a model for Emmental cheese based on measurements of water activity and $\mathrm{NaCl}$-in-moisture content during brining ( $a_{w}$ varying from 0.80 to 0.99 and $[\mathrm{NaCl}]_{\mathrm{H}_{2} \mathrm{O}}$ varying from an $\mathrm{NaCl}$-in-moisture of 0 to $30 \%$, wt/wt):

$$
a_{w}=0.997-0.00604 \cdot[\mathrm{NaCl}]_{\mathrm{H}_{2} \mathrm{O}} .
$$

So far, the effect of the $\mathrm{NaCl}$ content and the water content on water activity has not been investigated for Dutch-type cheeses. In the current study, we assessed the water activity of Gouda cheese based on migration of $\mathrm{NaCl}$ and water that occurs in the cheese during brining and ripening. An empirical model is presented and compared with the previous empirical models devel- 
oped for other types of cheeses. In addition, we predict the effect of water activity on inhibition of growth of $L$. monocytogenes. The results presented in this study are based on cheeses that were brined for $3.8 \mathrm{~d}$ and then foil-ripened, and on cheeses that were brined for different times and subsequently nature-ripened. The goals of this study were (1) to establish the diffusion of $\mathrm{NaCl}$ and water in Gouda cheese during brining and ripening, (2) to establish the water activity as a function of the $\mathrm{NaCl}$ content and the water content, and (3) to predict the effect of water activity on growth inhibition of microbial pathogens such as L. monocytogenes in Gouda cheese.

\section{MATERIALS AND METHODS}

\section{Manufacturing of Gouda Cheese, Brining, and Ripening Procedure}

Two block-type Gouda cheeses (weight $15.7 \mathrm{~kg}, 0.30$ $\times 0.50 \times 0.11 \mathrm{~m}, 48 \%$ fat in $\mathrm{DM})$ from one production lot, and 6 wheel-type Gouda cheeses (weight $4.5 \mathrm{~kg}$, height $0.097 \mathrm{~m}$, diameter $0.245 \mathrm{~m}, 48 \%$ fat in $\mathrm{DM}$ ) from one production lot were supplied by an industrial producer of pasteurized-milk Gouda cheeses in the Netherlands. Pressed fresh cheeses were transported in molds (protected with aseptic plastic bags) from the production location to NIZO Food Research (Ede, the Netherlands) and, within $3 \mathrm{~h}$ after pressing (as is common practice in Dutch-type Gouda cheese production), all cheeses were immersed in brine (consisting of $18.4 \%$ wt/vol $\mathrm{NaCl}$, with $\mathrm{pH}$ adjusted to 4.4 with $\mathrm{HCl}$ ) that was slowly but continuously agitated. The block-type cheeses were brined for $3.8 \mathrm{~d}$. Brining was performed at $12^{\circ} \mathrm{C}$. Of the 6 wheel-type cheeses, 2 cheeses (i.e., duplicate samples) were brined for $0.33 \mathrm{~d}, 2$ cheeses for $2.1 \mathrm{~d}$, and 2 cheeses for $8.9 \mathrm{~d}$, resulting in cheeses defined as low-salt, normal-salt and high-salt cheeses, respectively. The 2 cheeses brined for $2.1 \mathrm{~d}$ and the 2 block-type cheeses that were brined for $3.8 \mathrm{~d}$ had the same $\mathrm{NaCl}$-in-cheese content after 4 wk of ripening (both normal-salt cheeses).

After brining, the cheeses were removed in pairs and of each cheese, samples were taken independently before ripening started (for details, see Cheese Sampling section). Subsequently, the block-type cheeses were vacuumed using thermoforming polyamide/polyethylene (PA/PE) foil with a thickness of $100 \mu \mathrm{m}$ (Hevel, Zaandam, the Netherlands) and ripened at NIZO Food Research at $5^{\circ} \mathrm{C}$ and $62.5 \%$ humidity, as normally applied in Dutch cheese-making factories for this type of cheese. The wheel-type cheeses were coated with commercially available coating solution (CSK Food Enrichment, Ede, the Netherlands) containing 0.02\% natamycin as commonly applied for nature-ripened Gouda cheese to prevent growth of mold during ripening. The wheel-type cheeses were ripened at $12.5^{\circ} \mathrm{C}$ and $85 \%$ relative humidity at NIZO Food Research.

\section{Cheese Sampling}

Two different cheeses were analyzed per brining condition and each of these cheeses was sampled immediately after coating of the cheeses $(t=0)$ and after $2,4,7,12,19$, and 26 wk of ripening. Cheese samples (slices of 25-30 g) were taken at approximately 0.005, 0.025 , and $0.045 \mathrm{~m}$ from the rind of the cheese. From each slice of sampled cheese, the coating was removed and the slice was dissected to obtain 2 samples 0 to 0.01 $\mathrm{m}$ from the rind (cheese rind or the 0.005-m sample), 2 samples 0.02 to $0.03 \mathrm{~m}$ from the rind (0.025-m sample), and 1 sample 0.04 to $0.05 \mathrm{~m}$ from the rind (cheese core or the $0.045-\mathrm{m}$ sample), yielding 5 samples per cheese. Each cheese sample was grated and mixed to obtain a homogeneous sample. After grating, the samples were immediately stored in $180-\mathrm{mL}$ plastic sample containers with screw caps (VWR, Amsterdam, the Netherlands) at room temperature and analyzed within $2 \mathrm{~h}$ after storage to prevent water evaporation during sample preparation.

\section{Cheese Analysis}

Each cheese sample of 25 to $30 \mathrm{~g}$ was grated, and the $\mathrm{NaCl}$-in-cheese content, water-in-cheese content, and water activity were analyzed. The NaCl-in-cheese content was determined on the basis of the chloride content by a potentiometric titration of the chloride ions with silver nitrate according to Netherlands standard NEN 3762 (NEN, 1977). The NaCl-in-moisture (\%, wt/wt) was calculated from the NaCl-in-cheese content by multiplying the NaCl-in-cheese content (\%, wt/wt) by $100 \%$

water-in-cheese content (\%,wt/wt) . The water-incheese content $(\%, \mathrm{wt} / \mathrm{wt})$ was analyzed by determining the mass of the grated cheese sample before and after heating at $160^{\circ} \mathrm{C}$ in an oven (Kern MLS, Balingen, Germany) for 30 min according to NEN 3755 (NEN, 1998). The water activity was determined with an Aqualab Series 3 water activity measuring device (Decagon, Pullman, WA). All analyses were performed in duplicate, and the average value of each determination was reported. 


\section{Diffusion Coefficient of $\mathrm{NaCl}$ During Brining in Gouda Cheese}

Diffusion of NaCl-in-moisture (\%, wt/wt) was studied during brining of block-type and wheel-type Gouda cheeses. The displacement of $\mathrm{NaCl}$ in the vertical direction was assumed to be unaffected by the lateral displacements for both the block-type cheeses and the wheel-type cheeses, as the width was much greater than the height for both cheeses. Assuming no influence of lateral displacement, the diffusion coefficient, $D^{*}$, was established according to the error function (erf) for surface convection based on the diffusion law of Fick, as described by Geurts (1972):

$$
\frac{C^{\prime}-c}{C^{\prime}-C_{0}}=\operatorname{erf}\left(\frac{x}{2 \sqrt{\left(D^{*} t\right)}}\right),
$$

in which $C^{\prime}=$ concentration of $\mathrm{NaCl}$ at the rind in NaCl-in-moisture (\%, wt/wt), $c=$ concentration of $\mathrm{NaCl}$-in-moisture $(\%, \mathrm{wt} / \mathrm{wt})$ in the cheese sample, $C_{0}$ $=$ concentration of $\mathrm{NaCl}$-in-moisture $(\%, \mathrm{wt} / \mathrm{wt})$ in the cheese before brining, $x=$ distance $(\mathrm{m})$ from the rind in the direction to which $\mathrm{NaCl}$ has diffused, $t=$ brining time $(\mathrm{s})$, and $D^{*}=$ diffusion coefficient of NaCl-inmoisture (in $\left.\mathrm{m}^{2} \mathrm{~s}^{-1}\right)$.

The diffusion coefficient $D^{*}$ of $\mathrm{NaCl}$ during brining of Gouda cheese was calculated for each sample according to Equation [6]. In the initial unbrined cheeses, chloride ions were already present at a level of $0.39 \mathrm{~g} / 100 \mathrm{~g}$ of cheese moisture $\left(C_{0}=0.39 \%\right.$, wt $\left./ \mathrm{wt}\right)$ due to addition of calcium chloride $\left(\mathrm{CaCl}_{2}\right)$ to the cheese milk. The bulk concentration of $\mathrm{NaCl}$ in brine $\left(C^{\prime}\right)$ and the average diffusion coefficient $\left(D^{*}\right)$ were estimated using the Solver function in Excel (based on the minimal residual sum of squares between the measured and fitted values for $c$ determined per cheese sample) from Microsoft Office (Microsoft Corp., Redmond, WA).

\section{Deriving an Empirical Model for the Water Activity of Gouda Cheese}

An empirical model for the water activity as a function of the NaCl-in-moisture content of Gouda cheese was derived using linear regression (based on the highest $R^{2}$ value and an intercept of 0.995 , representing the water activity of Gouda before brining). This model was based on analysis of 70 samples from the block-type cheeses $(7$ ripening times $\times 2$ cheeses $\times 5$ samples per cheese) and 210 samples from the wheel-type cheeses $(7$ ripening times $\times 2$ cheeses $\times 3$ brining times $\times 5$ samples per cheese). The $\mathrm{NaCl}$ content was expressed as $\mathrm{NaCl}$-in-moisture (\%, wt/wt) to incorporate the changes in the water-in-cheese content of the cheese throughout ripening.

\section{Calculating the Effect of Water Activity on Growth Inhibition of L. monocytogenes}

The effect of water activity on inhibition of growth of L. monocytogenes was calculated using the previously established gamma factor for water activity $\gamma_{a_{w}}$ as described in Equation [2]; $\gamma_{a_{w}}$ was calculated at each location at which the $\mathrm{NaCl}$ content and water content were established in the cheese $(0.005,0.025$, or $0.045 \mathrm{~m}$ from the rind) and plotted against time for all types of cheeses (block-type cheeses that were brined for $3.8 \mathrm{~d}$ and wheel-type cheeses that were brined for $0.33,2.1$, or $8.9 \mathrm{~d}$ ). The lower the value of $\gamma_{a_{w}}$, the greater the effect of water activity on growth inhibition of L. monocytogenes in that cheese at that time. When, at a given time, $\gamma_{a_{w}}$ was equal to or lower than zero, water activity was predicted to fully inhibit growth of L. monocytogenes.

\section{RESULTS AND DISCUSSION}

\section{Diffusion Coefficient of $\mathrm{NaCl}$ in Gouda}

In this study, the diffusion of $\mathrm{NaCl}$ was determined in Dutch-type Gouda cheeses that were subjected to different brining times (Figure 1). The $D^{*}$ value of $\mathrm{NaCl}$ was determined during brining of Gouda cheeses produced in a Dutch cheese-making factory with, on average, a pH of 5.1 and water content of $47 \%$ before brining. The average $D^{*}$ value determined in this study was $3.6 \cdot 10^{-10} \mathrm{~m}^{2} \mathrm{~s}^{-1}$ in the $15.7-\mathrm{kg}$ block-type Gouda cheeses (Figure 1A) and $3.5 \cdot 10^{-10} \mathrm{~m}^{2} \mathrm{~s}^{-1}$ in the $4.5-\mathrm{kg}$ wheel-type Gouda cheeses (Figure 1B). The diffusion coefficients for $\mathrm{NaCl}$ as determined in the block-type and the wheel-type Gouda cheeses are in the range of those reported for Emmental, Cheddar, feta, and Camembert cheeses; namely, 1.0 to $5.3 \cdot 10^{-10} \mathrm{~m}^{2} \mathrm{~s}^{-1}$ (Floury et al., 2010). The diffusion coefficient of $\mathrm{NaCl}$ in Gouda cheese was higher than that reported by Geurts (1972), who calculated a $D^{*}$ value of 1.9 to $2.2 \cdot 10^{-10} \mathrm{~m}^{2} \mathrm{~s}^{-1}$ in Gouda cheese. The higher coefficient found in Gouda in this study than in Geurts (1972) might be explained by differences in processing conditions. Geurts (1972) did not add $\mathrm{CaCl}_{2}$ to the cheeses but left the freshly pressed cheeses for $2.5 \mathrm{~d}$ before brining to allow for further acidification and rind formation. The matrix and rind of the Gouda cheese of Geurts (1972) may have been more rigid and less permeable, which could explain the lower diffusion of $\mathrm{NaCl}$ in those cheeses. The higher $D^{*}$ value found in the current study compared with 

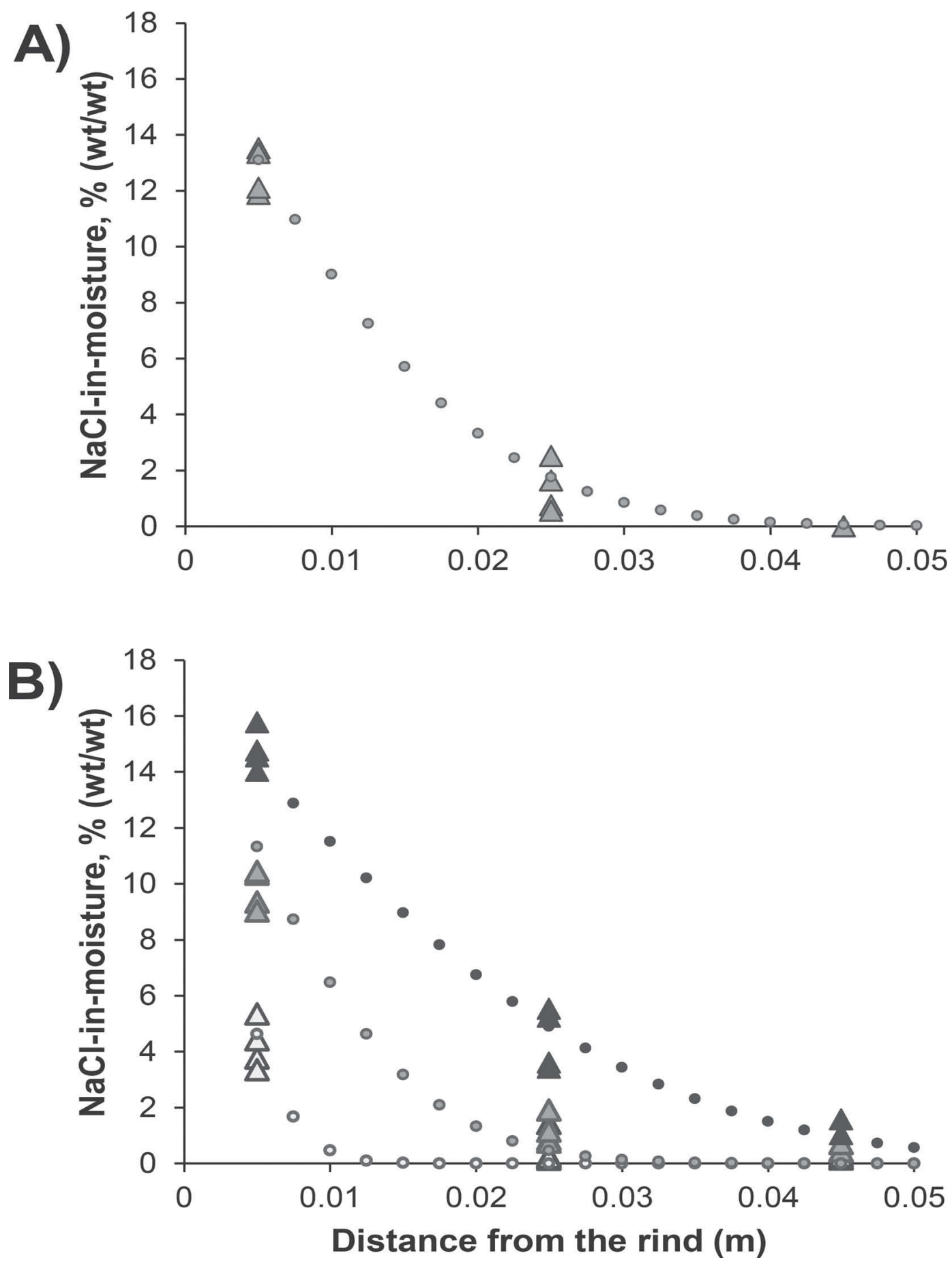

Figure 1. NaCl-in-moisture (\%, wt/wt) of Gouda cheeses immediately after brining. Samples were taken at distances of $0.005,0.025$, and $0.045 \mathrm{~m}$ from the rind of (A) 2 block-type cheeses of $15.7 \mathrm{~kg}$ that were brined for $3.8 \mathrm{~d}$ at $12^{\circ} \mathrm{C}$, and at $0.005,0.025$ and $0.045 \mathrm{~m}$ from the rind of (B) 6 wheel-type cheeses of $4.5 \mathrm{~kg}$ that were brined for $0.33 \mathrm{~d}$ (2 cheeses, white triangles), $2.1 \mathrm{~d}$ ( 2 cheeses, grey triangles), and $8.9 \mathrm{~d}$ ( 2 cheeses, black triangles) at $12^{\circ} \mathrm{C}$. Contents of $\mathrm{NaCl}$ for each distance are presented individually. The fitted $\mathrm{NaCl}$ contents (plotted as dotted lines) are based on concentration of NaCl-in-moisture $(\%, \mathrm{wt} / \mathrm{wt})$ in the cheese before brining $\left(C_{0}\right)=0.39 \%(\mathrm{wt} / \mathrm{wt})$, diffusion coefficient $\left(D^{*}\right)=3.6 \cdot 10^{-10}$ $\mathrm{m}^{2} \mathrm{~s}^{-1}$, and concentration of $\mathrm{NaCl}$ at the rind $\left(C^{\prime}\right)=17.7 \%$ (wt/wt) for the block-type cheeses and $D^{*}=3.5 \cdot 10^{-10} \mathrm{~m}^{2} \mathrm{~s}^{-1}$ and $C^{\prime}=17.2 \%$ (wt/ wt) for the wheel-type cheeses, as calculated using Equation [6], with the $\mathrm{NaCl}$ concentrations in the cheeses as predicted before and after brining, brining times, and distances from the rind as input parameters. 
Geurts (1972) may also be explained by the higher water-in-cheese content of cheeses before brining in this study than in Geurts (1972). When the water-in-cheese content is increased, the protein-in-cheese fraction will be decreased, leading to a lower rigidity of the cheese and a higher diffusion of $\mathrm{NaCl}$. In the study of Geurts (1972), the water-in-cheese content before brining was not reported, but the water-in-cheese content after 8.1 $\mathrm{d}$ of brining varied from $31 \%$ in the rind to $43 \%$ in the core. The water-in-cheese contents observed in this study were higher (38\% in the rind and $46 \%$ in the core after $8.9 \mathrm{~d}$ of brining). The initial water-in-cheese content of the cheeses of Geurts (1972) therefore appears to be $\sim 4 \%$ lower, likely explaining the reported lower $D^{*}$ values.

\section{Profiles of $\mathrm{NaCl}$ and Water During Ripening}

The gradient in NaCl-in-moisture (\%, wt/wt) disappeared in all cheeses during ripening (Figure 2A and 2B). Immediately after brining, the NaCl-in-moisture content was $\sim 9$ times higher in the rind than in the core for the wheel-type cheeses that were brined for 0.33, 2.1, or $8.9 \mathrm{~d}$. Not surprisingly, the highest concentration of $\mathrm{NaCl}$-in-moisture content was measured in the rind of the cheeses with the longest brining time $(8.9 \mathrm{~d}$; Figure 2B). Immediately after brining, the NaCl-in-moisture content was $5.1 \%$ (wt/wt), on average, in the blocktype Gouda cheeses that were brined for $3.8 \mathrm{~d}$ (Figure $2 \mathrm{~A})$. In wheel-type nature-ripened Gouda cheeses that were brined for $0.33,2.1$, and $8.9 \mathrm{~d}$, the average $\mathrm{NaCl}-$ in-moisture contents were $2.0,4.2$, and $7.2 \%$ (wt/wt), respectively. The average $\mathrm{NaCl}$-in-moisture content of the wheel-type nature-ripened cheeses increased to 4.8, 9.6, and $19.0 \%$ (wt/wt) after ripening for $26 \mathrm{wk}$ (Figure 2B); $\mathrm{NaCl}$ migrated from the outer to the inner layers of the cheese during ripening. According to Guinee and Fox (2004), it can take 9 wk for the $\mathrm{NaCl}$ gradient to disappear within large Gouda cheese blocks. In the 15.7-kg block-type cheeses that were wrapped in foil, the $\mathrm{NaCl}$ gradient disappeared between 4 and 7 wk of ripening, resulting in an average $\mathrm{NaCl}$-in-moisture content throughout the cheese of $5.3 \%$ (wt/wt; Figure 2A). After a similar time, the $\mathrm{NaCl}$-in-moisture gradient also disappeared in the wheel-type cheeses (Figure 2B).

The average water-in-cheese content in the blocktype cheeses that underwent foil-ripening was constant (Figure 3A) but decreased in the wheel-type cheeses that were nature-ripened (Figure 3B). The gradient in water-in-cheese content between rind and core had already disappeared in the block-type cheeses after 2 wk of ripening (Figure 3A), but persisted in the nature-ripened cheeses (due to evaporation, Figure 3B).
The average water-in-cheese content was lower in the cheese that was brined for $8.9 \mathrm{~d}$ than in the cheese that was brined for $0.33 \mathrm{~d}$, with a difference of $3.5 \%$ directly after brining and $2.2 \%$ after $26 \mathrm{wk}$ of ripening. Overall, an increase in the content of $\mathrm{NaCl}$-in-moisture was observed in the wheel-type cheeses during ripening (Figure 2B) due to an inward migration of $\mathrm{NaCl}$ and an outward migration of water.

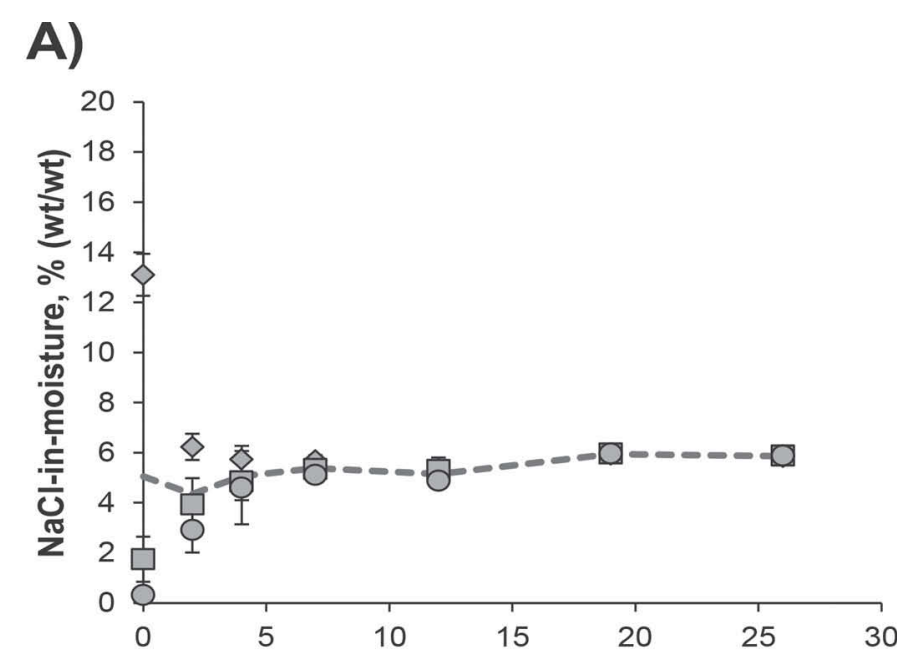

B)

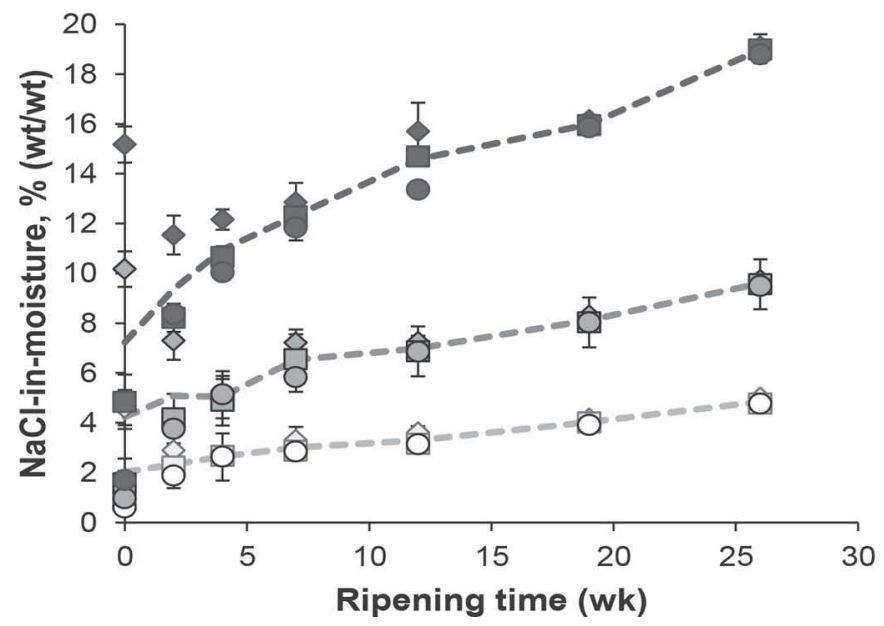

Figure 2. Sodium chloride ( $\mathrm{NaCl})$-in-moisture $(\%$, wt $/ \mathrm{wt})$ of Gouda cheese at different time points during ripening, showing the $\mathrm{NaCl}$ content (mean $\pm \mathrm{SD}$ ) in samples taken at different distances from the rind at each time point: $0.005 \mathrm{~m}$ from the rind (diamonds; $\mathrm{n}$ $=4$ ), $0.025 \mathrm{~m}$ from the rind (squares; $\mathrm{n}=4$ ), and $0.045 \mathrm{~m}$ from the rind (circles; $\mathrm{n}=2)$. In addition, the average NaCl-in-moisture $(\%$, $\mathrm{wt} / \mathrm{wt}$ ) is plotted (dashed lines) for each brining time in (A) blocktype foil-ripened cheese of $15.7 \mathrm{~kg}$ brined for $3.8 \mathrm{~d}$; and (B) wheel-type nature-ripened cheese of $4.5 \mathrm{~kg}$ brined for $0.33 \mathrm{~d}$ (open white symbols), $2.1 \mathrm{~d}$ (gray symbols), or $8.9 \mathrm{~d}$ (black symbols). 


\section{Water Activity During Ripening}

Figure 4 displays the water activity during ripening of Gouda cheese. In the block-type cheeses that were brined for $3.8 \mathrm{~d}$ and subsequently foil-ripened, the water activity in the rind immediately after brining was as low as 0.91 but rapidly increased to a value of 0.96 during ripening of the cheese (Figure 4A). Subsequently, the water activity in the foil-ripened cheeses was stable
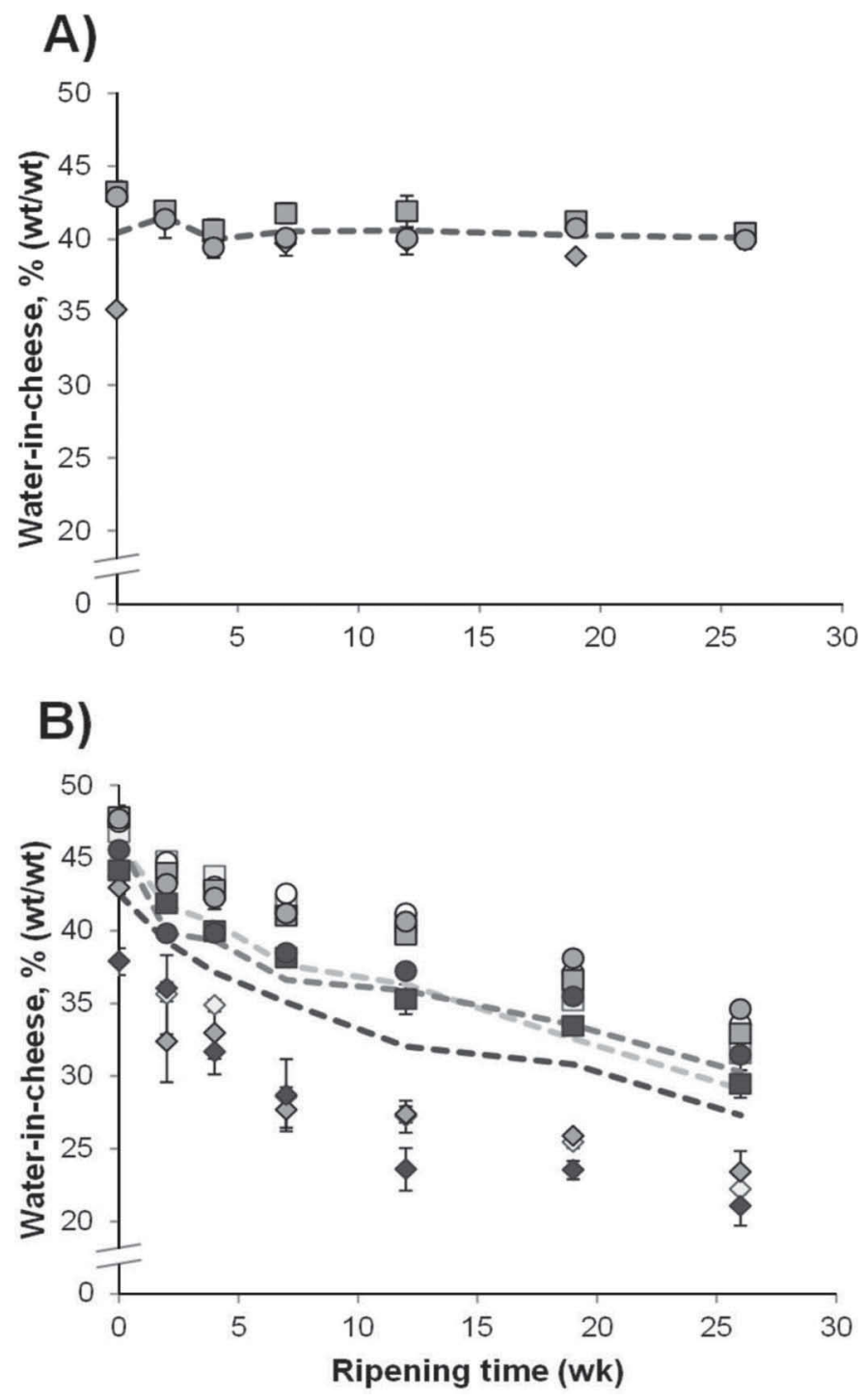

Figure 3. Water-in-cheese (\%,wt/wt) of Gouda cheese at different time points during ripening, showing the water-in-cheese content (mean $\pm \mathrm{SD}$ ) in samples taken at different distances from the rind at each time point: $0.005 \mathrm{~m}$ from the rind (diamonds; $\mathrm{n}=4$ ), $0.025 \mathrm{~m}$ from the rind (squares; $\mathrm{n}=4$ ), and $0.045 \mathrm{~m}$ from the rind (circles; $\mathrm{n}=$ $2)$. In addition, the mean water-in-cheese content (\%,wt/wt) is plotted (dashed lines) for each brining time in (A) block-type foil-ripened cheese of $15.7 \mathrm{~kg}$ brined for $3.8 \mathrm{~d}$; and (B) wheel-type nature-ripened cheese of $4.5 \mathrm{~kg}$ brined for $0.33 \mathrm{~d}$ (open white symbols), $2.1 \mathrm{~d}$ (gray symbols), or $8.9 \mathrm{~d}$ (black symbols).

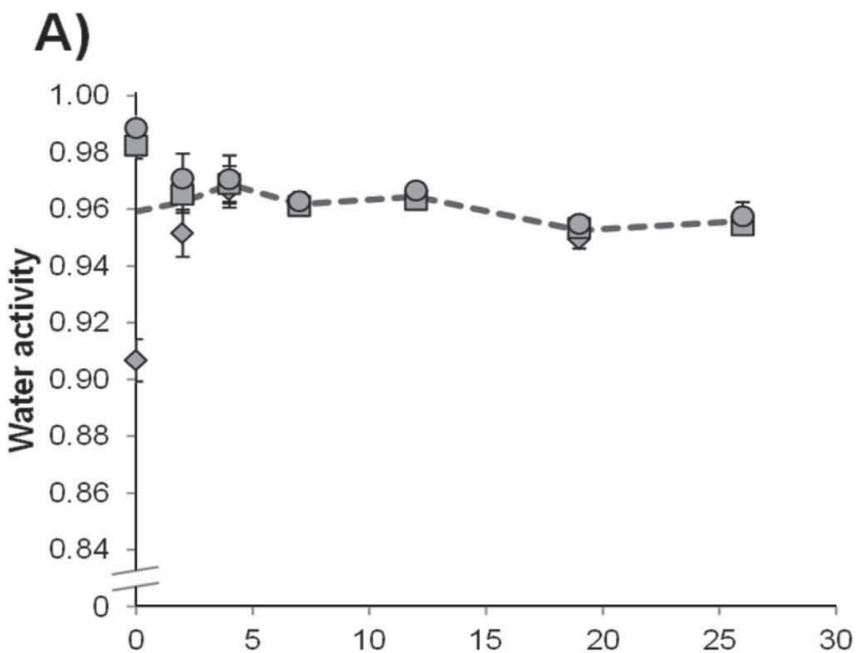

B)

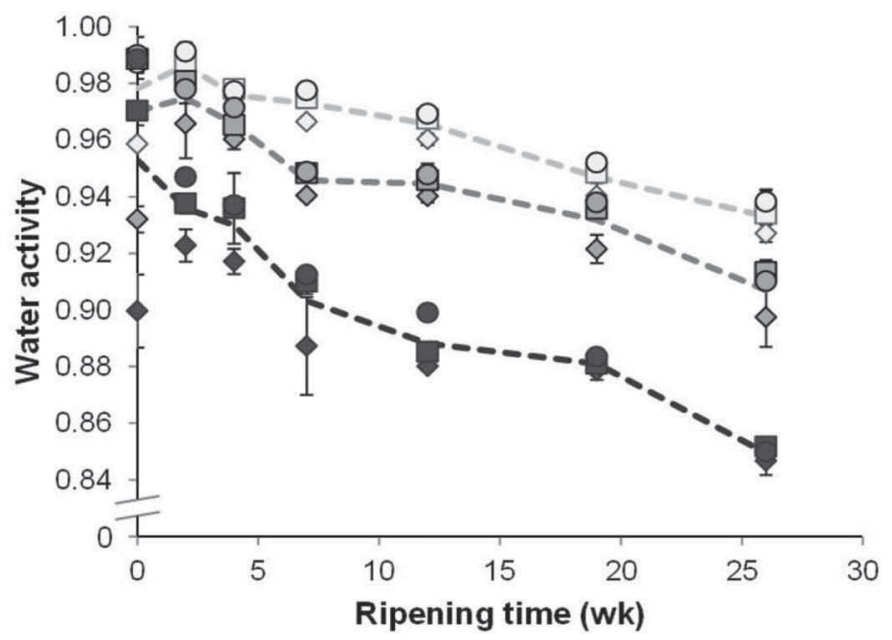

Figure 4. Water activity $\left(a_{w}\right)$ of Gouda cheese at different time points during ripening, showing the water activity (mean \pm SD) in samples taken at different distances from the rind at each time point: $0.005 \mathrm{~m}$ from the rind (diamonds; $\mathrm{n}=4$ ), $0.025 \mathrm{~m}$ from the rind (squares; $\mathrm{n}=4$ ), and $0.045 \mathrm{~m}$ from the rind (circles; $\mathrm{n}=2$ ). In addition, the average water activity is plotted (dashed lines) for each brining time in (A) block-type foil-ripened cheese of $15.7 \mathrm{~kg}$ brined for 3.8 $\mathrm{d}$; and (B) wheel-type nature-ripened cheese of $4.5 \mathrm{~kg}$ brined for $0.33 \mathrm{~d}$ (open white symbols), $2.1 \mathrm{~d}$ (gray symbols), or $8.9 \mathrm{~d}$ (black symbols).

during maturation because the foil prevented evaporation of water. In the nature-ripened cheeses, a decline in the average water activity was observed during ripening, concomitant with a reduction of the water-incheese content. Immediately after brining for $0.33,2.1$, and $8.9 \mathrm{~d}$, the water activity in the rind was $0.96,0.93$, and 0.90 , respectively, in the nature-ripened cheeses. The water activity in the core of these cheeses was 0.99 . The average water activity decreased from 0.98 to 0.93 in the cheeses that were brined for $0.33 \mathrm{~d}$, from 0.97 to 0.91 in the cheeses that were brined for $2.1 \mathrm{~d}$, and 
from 0.95 to 0.85 in the cheeses that were brined for $8.9 \mathrm{~d}$ between 0 and $26 \mathrm{wk}$ of ripening. The differences in water activity values observed after brining between the cheeses that were brined for $0.33,2.1$, and $8.9 \mathrm{~d}$ persisted during maturation (Figure 4B).

\section{Empirical Model for Water Activity of Gouda Cheese}

An empirical model $\left(\mathrm{R}^{2}=0.89\right.$, regression coefficient $-0.00721 \pm-0.0003$ ) for the water activity of Gouda cheese as a function of the $\mathrm{NaCl}$-in-moisture content was derived (based on the data presented in Figure 5):

$$
a_{w}=0.995-0.00721 \cdot \mathrm{NaCl}_{\mathrm{H}_{2} \mathrm{O}} .
$$

Freshly pressed but unsalted cheese already contains some solutes, rendering a water activity of 0.995 (water activity of pure water is 1.000). Therefore, the latter value was used as intercept in the empirical model. The model presented here is independent of time and is valid during brining and ripening. It incorporates both the $\mathrm{NaCl}$ content and the water content, which are the main factors that change during brining and ripening of Gouda cheese. The model presented here is similar to the empirical model for water activity of Emmental cheese during brining, as derived by Saurel et al. (2004) in Equation [5]. That model likely resembles the empirical model for Gouda, because part of the $a_{w} / \mathrm{NaCl}_{\mathrm{H}_{2} \mathrm{O}}$ intervals of Gouda were similar to that of Emmental cheese (the $\mathrm{a}_{w}$ and $\mathrm{NaCl}_{\mathrm{H}_{2} \mathrm{O}}$ of aged Gouda cheese seem similar to those of fresh Emmental). The $\mathrm{R}^{2}(0.89)$ and the regression coefficient $(-0.00721)$ in this empirical model are lower than those in the model of Saurel et al. (2004; $\mathrm{R}^{2}$ of 0.98 and a regression coefficient of $-0.00604)$, but that model was based only on samples taken during brining, and it does not include samples during ripening. The regression coefficient of -0.00721 that we established (see Equation [7]) was smaller than that determined by Marcos et al. $(1981,1983)$. This implies that the effect of the $\mathrm{NaCl}_{\mathrm{H}_{2} \mathrm{O}}$ factor on water activity is greater than expected based on the data of the latter reports. Moreover, our empirical model has a broader scope because it also includes cheeses with a water-in-cheese content $<40 \%$ and a water activity $<0.96$.

\section{Implications of Reduced Brining Time and Foil- Ripening for $L$. monocytogenes}

Immediately after brining, water activities were 0.93 and 0.90 in the outer layer of the cheeses that were brined for 2.1 and $8.9 \mathrm{~d}$, respectively. These values are close to or lower than the $a_{w}$ growth limit for $L$. monocytogenes. Such low water activities in the outer layer of the cheese can likely hinder outgrowth of $L$. monocytogenes in Gouda cheese following a contamination after curd formation (e.g., by the brine bath or conveyors). Such conditions may even lead to inactivation of the pathogen, as was observed by Wemmenhove et al. (2014).

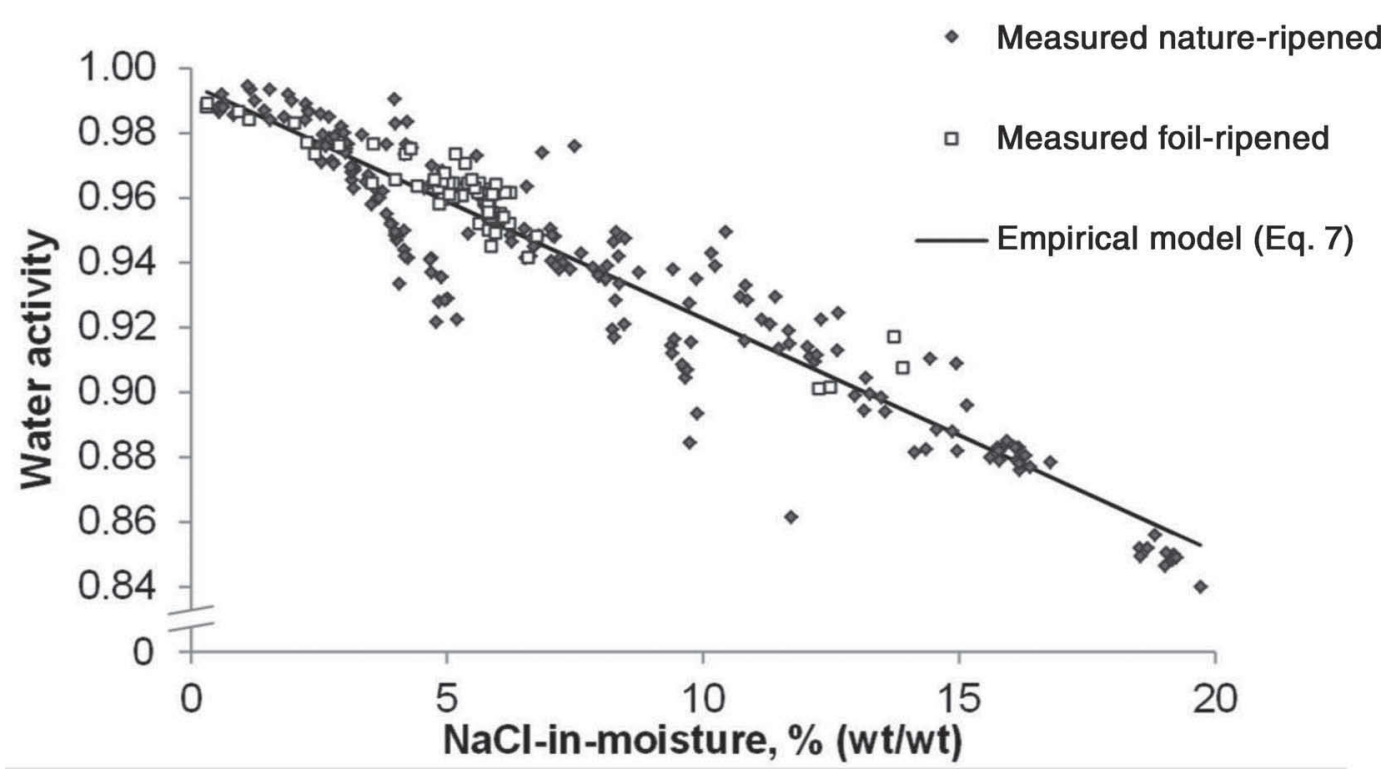

Figure 5. Empirical model $\left(\mathrm{R}^{2}=0.89\right)$ for the water activity $\left(a_{w}\right)$ of Gouda cheese as a function of the NaCl-in-moisture content $\left(\mathrm{NaCl}_{\mathrm{H}_{2} \mathrm{O}}\right)$ in \%, wt/wt: $a_{w}=0.995-0.00721 \cdot \mathrm{NaCl}_{\mathrm{H}_{2} \mathrm{O}}($ with $-0.00721 \pm-0.0003)$. 
Food producers that use foil-ripening or that shorten their brining times (e.g., to produce low-salt cheeses) must be aware that a lower salt content and a higher water content can have a negative effect on inhibition of bacterial growth. A lower salt content or a higher water content results in a reduced water activity hurdle for microbial pathogens. According to the Gamma model described in Equation [2], a shortened brining time will lead to a higher $a_{w}$ and a smaller effect on inhibition of growth. The water activity was 0.96 in the outer layer of the cheese immediately after brining when cheeses were brined for only $0.33 \mathrm{~d}$. In addition to water activity, other microbial hurdles (e.g., $\mathrm{pH}$ and the presence of organic acid) are present in cheese that can contribute to full inhibition of growth of L. monocytogenes or other pathogens, even at higher water activity values, such as occurring in foil-ripened cheeses and in cheeses with shortened brining times. Figure 6 displays the effect of water activity $\left(\gamma_{a_{w}}\right)$ on growth inhibition of L. monocytogenes during ripening, as predicted from
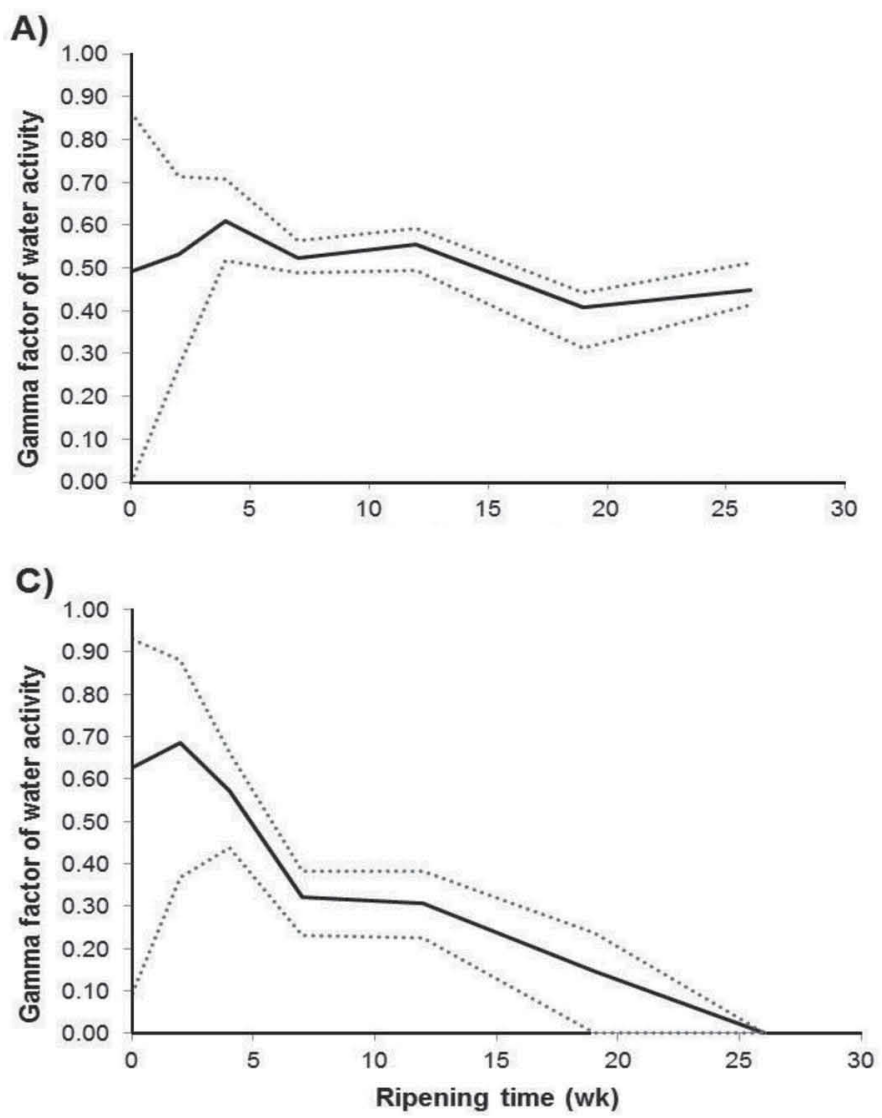

the Gamma model. The effect of water activity on growth inhibition of $L$. monocytogenes in foil-ripened cheese seems stable during ripening (Figure 6A), as the average water activity during ripening is stable within this type of cheese (Figure 4A). Full growth inhibition of $L$. monocytogenes as a result of low water activity can be expected after 26 wk of ripening in Gouda cheese that was brined for $2.1 \mathrm{~d}$; in the nature-ripened cheeses, the $a_{w}$ then decreased to values below the critical $a_{w}$ limit for growth of L. monocytogenes (Figure 6C).

We recently demonstrated absence of growth of $L$. monocytogenes in and on Gouda cheese (Wemmenhove et al., 2013, 2014), and furthermore showed that the concentrations of undissociated lactate that are present in Gouda cheese contribute significantly to the inhibition of growth of this pathogen (Wemmenhove et al., 2016). The current study shows that low water activity can also contribute significantly to inhibition of growth of this bacterium in cheese. Conditions of low water activity may completely suppress growth of L. monocytogenes. In fact, inactivation of L. monocytogenes in

B)
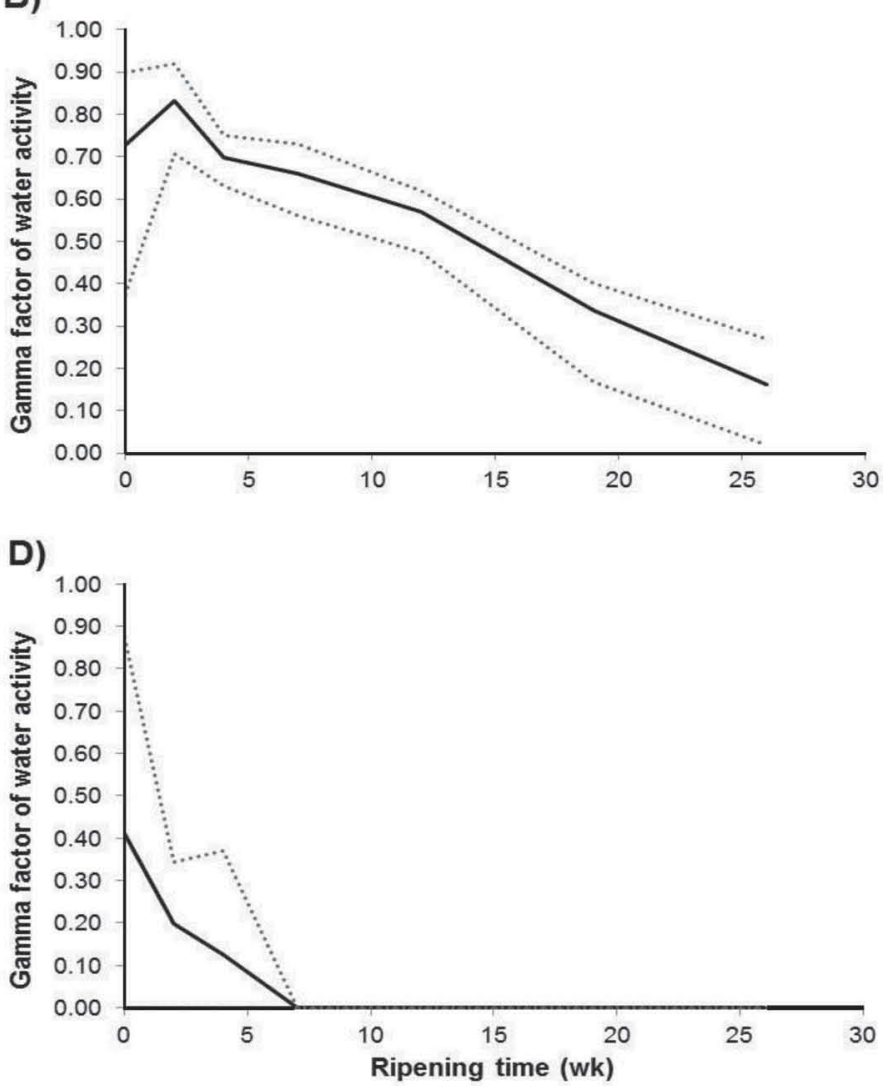

Figure 6. The effect of water activity $\left(\gamma_{a_{w}}\right)$ on growth inhibition of Listeria monocytogenes during ripening as predicted from the Gamma model, with (A) foil-ripened block-type Gouda cheeses that were brined for $3.8 \mathrm{~d}$ at $12^{\circ} \mathrm{C}$ and with nature-ripened wheel-type Gouda cheeses that were brined for (B) $0.33 \mathrm{~d}$, (C) $2.1 \mathrm{~d}$, or (D) $8.9 \mathrm{~d}$ at $12^{\circ} \mathrm{C}$. Dotted lines present the minimum (_MIN) and maximum (_MAX) gamma factors; straight lines are the average gamma factors of water activity within Gouda cheese at the indicated ripening time. 
model Gouda cheeses was seen after 28 wk of ripening when $a_{w}$ decreased below 0.92 ; that is, the minimum $a_{w}$ required for growth of L. monocytogenes (Wemmenhove et al., 2013). These findings are in line with the study of Koutsoumanis and Sofos (2005), who showed that growth of L. monocytogenes was inhibited at an $a_{w}$ lower than 0.93 in combination with a $\mathrm{pH}$ lower than 5.0 in tryptic soy broth.

Overall, this study provides an empirical model for water activity as a function of the $\mathrm{NaCl}$ and water content and underlines the importance of $a_{w}$ as a factor that can lead to inhibition of growth of L. monocytogenes in Gouda cheese.

\section{ACKNOWLEDGMENTS}

This study was supported by the Dutch Dairy Organization (The Hague, the Netherlands) and the Dutch Dairy Board (The Hague, the Netherlands).

\section{REFERENCES}

Bachmann, H. P., and U. Spahr. 1995. The fate of potentially pathogenic bacteria in Swiss hard and semihard cheeses made from raw milk. J. Dairy Sci. 78:476-483.

Buazzi, M. M., M. E. Johnson, and E. H. Marth. 1992. Survival of Listeria monocytogenes during the manufacture and ripening of Swiss cheese. J. Dairy Sci. 75:380-386.

European Commission. 2005. Commission regulation (EC) No 2073/2005 of 15 November 2005 on microbiological criteria for foodstuffs. Off. J. Eur. Commun. 48:1-26.

Floury, J., S. Jeanson, S. Aly, and S. Lortal. 2010. Determination of the diffusion coefficients of small solutes in cheese: A review. Dairy Sci. Technol. 90:477-508.

Gaulin, C., D. Ramsay, and S. Bekal. 2012. Widespread listeriosis outbreak attributable to pasteurized cheese, which led to extensive cross-contamination affecting cheese retailers, Quebec, Canada, 2008. J. Food Prot. 75:71-78.

Geurts, T. J. 1972. Diffusie van zout en water bij het zouten van kaas. PhD Thesis. Wageningen University, Wageningen, the Netherlands. http://edepot.wur.nl/194048.

Gould, L. H., E. Mungai, and C. Barton Behravesh. 2014. Outbreaks attributed to cheese: Differences between outbreaks caused by unpasteurized and pasteurized dairy products, United States, 19982011. Foodborne Pathog. Dis. 11:545-551.

Greig, J. D., and A. Ravel. 2009. Analysis of foodborne outbreak data reported internationally for source attribution. Int. J. Food Microbiol. 130:77-87.

Guinee, T. P., and P. F. Fox. 2004. Salt in cheese: Physical, chemical and biological aspects. Pages 206-259 in Cheese: Chemistry, Physics and Microbiology. Vol. 1. 3rd ed. Elsevier Academic Press, San Diego, CA.

ICMSF (International Commission on Microbiological Specifications for Foods). 1996. ICMSF 5: Microorganisms in Foods: Microbiological Specifications of Food Pathogens. Blackie, London, UK.

Koch, J., R. Dworak, R. Prager, B. Becker, S. Brockmann, A. Wicke, H. Wichmann-Schauer, H. Hof, D. Werber, and K. Stark. 2010. Large listeriosis outbreak linked to cheese made from pasteurized milk, Germany, 2006-2007. Foodborne Pathog. Dis. 7:1581-1584.

Koutsoumanis, K. P., and J. N. Sofos. 2005. Effect of inoculum size on the combined temperature, $\mathrm{pH}$ and aw limits for growth of Listeria monocytogenes. Int. J. Food Microbiol. 104:83-91.
Lou, Y., and A. E. Yousef. 2000. Characteristics of Listeria monocytogenes important to food processors. Pages 131-224 in Listeria, Listeriosis and Food Safety. E. T. Ryser, and E. H. Marth, ed. Marcel Dekker, New York, NY.

Marcos, A., M. Alcalá, F. León, J. Fernández-Salguero, and M. A. Esteban. 1981. Water activity and chemical composition of cheese. J. Dairy Sci. 64:622-626.

Marcos, A., R. Millán, M. A. Esteban, M. Alcalá, and J. FernandezSalguero. 1983. Chemical composition and water activity of Spanish cheeses. J. Dairy Sci. 66:2488-2493.

NEN. 1977. Cheese-Physical and chemical test methods-Determination of the chloride content (routine method). NEN-3762:1977. NEN, Delft, the Netherlands.

NEN. 1998. Cheese-Physical and chemical test methods-Determination of the moisture content. NEN-3755:1998. NEN, Delft, the Netherlands.

Northolt, M. D., H. J. Beckers, U. Vecht, L. Toepoel, P. S. S. Soentoro, and H. J. Wisselink. 1988. Listeria monocytogenes: Heat resistance and behaviour during storage of milk and whey and making of Dutch types of cheese. Neth. Milk Dairy J. 42:207-219.

Resnik, S. L., and J. Chirife. 1988. Proposed theoretical water activity values at various temperatures for selected solutions to be used as reference sources in the range of microbial growth. J. Food Prot. 51:419-423.

Saurel, R., A. Pajonk, and J. Andrieu. 2004. Modelling of French Emmental cheese water activity during salting and ripening periods. J. Food Eng. 63:163-170.

Schlech, W. F., P. M. Lavigne, R. A. Bortolussi, A. C. Allen, E. V. Haldane, A. J. Wort, A. W. Hightower, S. E. Johnson, S. H. King, E. S. Nichols, and C. V. Broome. 1983. Epidemic listeriosis-evidence for transmission by food. N. Engl. J. Med. 308:203-206.

Silk, B. J., K. A. Date, K. A. Jackson, R. Pouillot, K. G. Holt, L. M. Graves, K. L. Ong, S. Hurd, R. Meyer, R. Marcus, B. Shiferaw, D. M. Norton, C. Medus, S. M. Zansky, A. B. Cronquist, O. L. Henao, T. F. Jones, D. J. Vugia, M. M. Farley, and B. E. Mahon. 2012. Invasive listeriosis in the foodborne diseases active surveillance network (FoodNet), 2004-2009: Further targeted prevention needed for higher-risk groups. Clin. Infect. Dis. 54:S396-S404.

Swaminathan, B., and P. Gerner-Smidt. 2007. The epidemiology of human listeriosis. Microbes Infect. 9:1236-1243.

Vázquez-Boland, J. A., M. Kuhn, P. Berche, T. Chakraborty, G. Dominguez-Bernal, W. Goebel, B. Gonzalez-Zorn, J. Wehland, and J. Kreft. 2001. Listeria pathogenesis and molecular virulence determinants. Clin. Microbiol. Rev. 14:584-640.

Wemmenhove, E., R. R. Beumer, A. C. M. Hooijdonk, M. H. Zwietering, and M. H. J. Wells-Bennik. 2014. The fate of Listeria monocytogenes in brine and on Gouda cheese following artificial contamination during brining. Int. Dairy J. 39:253-258.

Wemmenhove, E., I. Stampelou, A. C. M. van Hooijdonk, M. H. Zwietering, and M. H. J. Wells-Bennik. 2013. Fate of Listeria monocytogenes in Gouda cheese: No growth, and substantial inactivation after extended ripening times. Int. Dairy J. 32:192-198.

Wemmenhove, E., H. J. F. van Valenberg, M. H. Zwietering, A. C. M. van Hooijdonk, and M. H. J. Wells-Bennik. 2016. Minimal inhibitory concentrations of undissociated lactic, acetic, citric and propionic acid for Listeria monocytogenes under conditions relevant to Dutch-type cheeses. Food Microbiol. http://dx.doi.org/10.1016/j. fm.2016.03.012.

Yde, M., M. Naranjo, W. Mattheus, P. Stragier, B. Pochet, K. Beulens, K. de Schrijver, D. van den Branden, V. Laisnez, W. Flipse, A. Leclercq, M. Lecuit, K. Dierick, and S. Bertrand. 2012. Usefulness of the European epidemic intelligence information system in the management of an outbreak of listeriosis, Belgium, 2011. Euro Surveill. 17:38.

Zwietering, M. H., T. Wijtzes, F. M. Rombouts, and K. van 't Riet. 1993. A decision support system for prediction of microbial spoilage in foods. J. Ind. Microbiol. 12:324-329. 